\title{
REFORMULASI PARADIGMA KAJIAN KEISLAMAN DI PERGURUAN TINGGI AGAMA ISLAM (PTAI)
}

\author{
Oleh: Saifullah \\ Dosen Fakultas Tarbiyah IAIN Ar-Raniry Banda Aceh
}

\begin{abstract}
In the midst of highly rapid social changes, currently the PTAIs /IAINs are facing various problems. On one hand, the PTAIs / IAINs are in crucial period of their development, while on the other hand, the PTAIs are also at the intersection between: 1) various scientific traditions, 2) state and civil society, and, 3) science and religious education and general studies. Therefore, in the face of these issues, PTAI must seek to respond to the existing challenges and the need to reformulate a new paradigm in accordance with the needs of society, which rest on three main pillars, namely independency in management or autonomy, accountability and quality assurance, and with reference to the Three Responsibilities of Higher Education: education / teaching, community service and research. This paper tries to describe how PTAI provides efforts in response to changes in the surrounding and any attempt to do by PTAI in accordance with the global market demands while characterizing the Islamic professionalism.
\end{abstract}

Keywords: Reformulation, Paradigm, Islamic Studies, PTAI

\section{Abstrak}

Di tengah perubahan sosial masyarakat yang begitu cepat, saat ini PTAI/IAIN dihadapkan pada berbagai persoalan. Satu sisi PTAI/IAIN berada pada periode sangat menentukan dalam perkembangannya; sementara di lain pihak PTAI juga berada pada titik temu antara: 1) berbagai tradisi ilmiah, 2) negara dan masyarakat sipil, dan, 3) ilmu pengetahuan dan pendidikan agama serta ilmu pengetahuan umum. Oleh karena itu, dalam menghadapi persoalan tersebut, PTAI mesti berupaya merespon tantangan yang ada dan perlunya mereformulasikan kembali paradigma baru sesuai kebutuhan masyarakat yang bertumpu pada tiga pilar utama, yaitu kemandirian dalam pengelolaan atau otonomi, akuntabilitas (accuntability) dan jaminan mutu (quality assurance), serta dengan mengacu kepada Tridharma Perguruan Tinggi yaitu: pendidikan/pengajaran, pengabdian masyarakat dan penelitian. Tulisan ini berusaha mendeskripsikan bagaimana upaya PTAI dalam merespon perubahan yang terjadi sekitarnya dan upaya apa saja yang harus dilakukan PTAI sesuai dengan tuntutan pasar global dan tetap mencirikan profesionalitas keislaman-nya.

Kata Kunci: Reformulasi, Paradigma, Kajian Islam, PTAI

\section{PENDAHULUAN}

Pada saat ini, Perguruan Tinggi Agama Islam (PTAI) khususnya IAIN dan STAIN telah dan sedang dihadapkan pada persoalan besar dan mendasar. Persoalan terse- but adalah menyangkut tentang out putnya yang hingga kini belum terakomodasi (terlibat/dilibatkan) secara memadai, jika tidak dikatakan secara maksimal ke dalam berbagai aspek kebutuhan kehidupan modern. Padahal tuntutan perubahan terus

Naskah diterima 20 Mei 2012. Revisi pertama, 6 juni 2012. Revisi kedua, 18 Juni 2012 dan revisi terakhir 28 Juni 2012 
menggelinding seiring dengan perubahan zaman yang seakan-akan tak dapat dibendung. Persoalan demikian ternyata tidak hanya menimpa PTAI di Indonesia, namun juga telah menggejala hampir di sebagian besar Perguruan Tinggi Agama Islam di belahan dunia.

Sebagaimana dilaporkan Bassam Tibi dari hasil penelitiannya, bahwa hampir seluruh universitas Islam di kawasan Timur Tengah dan Afrika, dia tidak menyebut Indonesia sangat menekankan kapasitas untuk menghafal agar mahasiswa dapat lulus dalam studi mereka; tidak pada kapasitas untuk berfikir kritis dan analitis. Mahasiswa dipersiapkan bukan untuk menjawab tantangan perubahan, tetapi untuk stabilisasi dan gengsi. Alhasil, setelah lulus dari studi, para mahasiswa lebih dibekali dengan ijazah, tetapi tidak dengan kualifikasi yang dapat diterapkan secara bermanfaat dalam proses pembangunan. Tamatan universitas pada umumnya dalam masyarakat, pertama kali tidak ditanya tentang bidang keahlian dan kualifikasi mereka, tetapi tentang gelar akademis yang mereka sandang, dan dari universitas mana mereka peroleh. ${ }^{1}$ Pendapat Tibi di atas kiranya sama dengan kondisi Perguruan Tinggi Islam yang ada di Indonesia. Seperti dilaporkan Azyumardi Azra, bahwa mahasiswa di Indonesia belajar ke Perguruan Tinggi pertama-tama adalah untuk mengejar status dan selembar ijazah, bukan keahlian, keterampilan dan profesionalisme. $^{2}$

Kenyataan yang dilaporkan Tibi dan Azra di atas, tampaknya tidak dapat disalahkan ataupun dibenarkan seluruhnya, walaupun dinyatakan pada tahun 90-an jika dilihat kondisi out put PTAI hingga saat ini, pendapat tersebut sepertinya cu-

${ }^{1}$ Bassam Tibi. 1991. Islam and the Cultural Accommodation of Social Change. h. 110.

${ }^{2}$ Azyumardi Azra. Pendidikan Tinggi Islam dan Kemajuan Sains (Sebuah Pengantar), dalam Charles Michael Stanton, Pendidikan Tinggi dalam Islam, (terj.) 1994. H. Afandi dan Hasan Asari. Jakarta: Logos, h. $\mathrm{xv}$. kup beralasan. Kondisi demikian, paling tidak dapat dibuktikan melalui kajian-kajian empiris yang masih sangat terasa di sebagian PTAI, walaupun tidak sedikit juga ditemukan Perguruan Tinggi Islam yang telah dan sedang melakukan berbagai inovasi dan transformasi baik dari aspek keilmuan maupun aspek-aspek teknis-akademis lainnya. Kajian empiris tersebut paling tidak dapat dilihat dari dua hal, antara lain: pertama, di satu sisi, sebagian besar lulusan (alumni) PTAI terlihat tidak dan atau kurang percaya diri dalam merebut peluang kerja jika dibandingkan dengan para lulusan dari Perguruan Tinggi Umum (PTU) lainnya. ${ }^{3}$ Persoalan ini muncul sebagai konsekuensi logis kompleksitas permasalahan yang dihadapi PTAI pada umumnya mulai dari belum jelasnya landasan epistemologi keilmuan yang dibangun, visi-misinya (sebagai lembaga dakwah, akademis atau praktis-pragmatis?) yang juga belum jelas, sampai kepada persoalan kurikulum, SDM pengelolanya, minimnya anggaran dana yang tersedia, terbatasnya bangunan kerjasama (stakeholders), sarana-prasarana

${ }^{3}$ Fenomena di atas sebenarnya merupakan fenomena yang tidak hanya terjadi pada PTAI semata, namun juga pada Perguruan Tinggi Umum (PTU). Menurut data yang berhasil dihimpun, jumlah sarjana menganggur melonjak drastis dari 183.629 orang pada tahun 2006 menjadi 409.890 orang pada tahun 2007, ditambah pemegang gelar Diploma I, II, dan III yang menganggur berdasarkan pendataan 2007, lebih dari 740.000 orang. Direktur Jendral Pendidikan Tinggi, Fasli Jalal menyatakan, saat ini di Indonesia ada 740.206 lulusan perguruan tinggi yang menganggur. Mereka terdiri atas 151.085 lulusan D-1 atau D-2; 179.231 lulusan D-3; dan 409.890 lulusan universitas. Mereka tidak bekerja karena kompetensi tida sesuai, lulusan yang tidak terserap, memilih untuk tidak bekerja, atau mahasiswa lulusan dari program studi yang sudah jenuh $(05 / 02 / 2009)$. Sementara pada Agustus 2007, Badan Pusat Statistik merilis angka pengangguran yang mencapai 10,01 juta orang atau turun $8,42 \%$ jika dibandingkan dengan angka pengangguran per Agustus 2006 sebanyak 10,93 juta jiwa. BPS juga mencatat, tingkat pengangguran terbuka pada Agustus 2007 mencapai 10,28\% atau turun bila dibandingkan dengan angka pengangguran terbuka pada Agustus 2006 sebesar 10,28\%. Lihat Siti Muyassarotul H. "Ironi Pengangguran Kaum Terpelajar" dalam Jawa Pos, Selasa 29 September 2009). 
yang kurang memadahi, dan sebagainya. Kedua, di lain sisi, barangkali juga tidak dapat menutup mata terhadap peran dan kiprah para alumni PTAI dalam perkembangan masyarakat Indonesia selama ini. Tidak sedikit alumninya yang muncul sebagai sosok pemikir, wartawan, bahkan juga politisi di pentas nasional. ${ }^{4}$ Tentu saja sulit untuk menyimpulkan bahwa prestasi tersebut berkat kurikulum yang mereka pelajari ketika menjadi mahasiswa. Akan tetapi, sebagai sebuah institusi, PTAI telah berfungsi dengan baik dalam menyediakan ruang pengembangan bakat-bakat para warganya.

Jika mangikuti identifikasi permasalahan Perguruan Tinggi Islam yang dibuat Tibi dan Azra di atas, maka problem yang sedang dihadapi PTAI adalah: (1) Kurang tumbuhnya tradisi berfikir kritis dan analitis, (2) Mahasiswa tidak dibekali dengan bidang keahlian dan kualifikasi yang dapat diterapkan secara bermanfaat dalam proses pembangunan, dan (3) Mahasiswa ke Perguruan Tinggi pertama-tama adalah untuk mengejar status dan selembar ijazah, bukan keahlian, ketrampilan dan profesionalisme.

Di samping problem-problem besar di atas, nampaknya masih banyak problem yang hingga kini masih sering disaksikan, misalnya: (1) Bagaimana bangunan epistimologi keilmuan yang dikembangkan PTAI selama ini, apakah sudah tepat, kurang tepat, dan atau tidak tepat sama sekali? Jika demikian, bagaimana pemecahannya? Pertanyaan ini penting diajukan, mengingat struktur keilmuan (keagamaan) Islam yang dikembangkan di PTAI pada umumnya selama ini cenderung terkesan dikotomis (jika tidak disebut antagonis) terhadap ilmuilmu ke-Islaman dan ilmu-ilmu umum (sosial); (2) Jika demikian, apakah masih perlu dilakukan transformasi/konversi, misal-

${ }^{4}$ Komaruddin Hidayat dan Hendro Prasetiyo (ed.), "Menilik Dinamika IAIN", dalam Problem dan Prospek IAIN:Antologi Pendidikan Tinggi Islam, (Ditpertais Depag. RI., 2000), hal. xxvi. nya Institut menjadi Universitas, dan atau Sekolah Tinggi menjadi Institut? Pertanyaan ini juga penting diangkat, sebab sebagian besar praktisi dan penentu kebijakan pendidikan di Negeri ini masih menganggap "institusi" sebagai hal sangat penting, sehingga perubahan-perubahan tidak bisa dilakukan tanpa melakukan perubahan terhadap institusinya terlebih dahulu; (3) Bagaimana dengan SDM yang dimiliki PTAI, apakah sudah benar-benar siap dalam menghadapi akselarasi yang terjadi, baik yang menyangkut masalah-masalah sosial, budaya, politik, maupun ekonomi?; dan (4) Persoalan yang tidak kalah penting adalah bagaimana dengan kurikulum, kesediaan dana, dan sarana-prasarana, sistem kerja sama dengan pihak lain (stakeholders), baik negeri, swasta, dalam negeri dan luar negeri, apakah sudah cukup memadai atau belum?

Tulisan ini akan berusaha mendiskusikan dengan mengaitkan berbagai kondisi dan kebutuhan, tentunya juga diusahakan menampilkan berbagai solusi alternatif dalam pengembangan PTAI ke depan.

\section{PEMBAHASAN}

Konsekuensi di balik Institut, Universitas, Ataupun Sekolah Tinggi

Ada hal penting yang mesti diklarifikasi terlebih dahulu sebelum dibahas mengenai substansi pembahasan dalam tulisan ini, sehingga tidak terjebak kepada istilahistilah teknis-pragmatis dalam pemahaman selanjutnya. Hal ini penting dikemukakan, mengingat sebagian besar dari komunitas kampus, khususnya para penentu kebijakan pendidikan di Negeri ini, masih menganggap bahwa persoalan wadah (institusi) adalah masalah pertama dan utama sebelum berbicara tentang isi dan substansinya. Hal ini dapat diibaratkan sebuah rumah dan isi rumah/perabot. Memang cukup dilematis, jika berbicara tentang bangunan rumah, tentunya akan berfikir bagaimana 
rumah itu bisa terisi. Begitu juga ketika berbicara tentang isi rumah/perabot, maka yang ada dalam benak kita adalah di mana isi rumah/perabot tersebut ditempatkan.

Terkait dengan hal tersebut, bagaimana melihat kembali tentang makna Institut, Universitas, ataupun Sekolah Tinggi. Hal ini penting dikemukakan, mengingat istilah-istilah teknis tersebut seringkali membuat kita terbatasi, yang pada gilirannya berakibat pada "tidak leluasanya" untuk mencoba melakukan perubahan-perubahan di dalamnya bila hal tersebut dirasa perlu dan penting. Di antara contoh mutakhir yang dapat dikemukakan adalah adanya ungkapan, bahwa sebuah Institut Agama Islam (IAI) tidak akan dapat melakukan transformasi/konversi ilmu-ilmu ke-Islamannya dengan ilmu-ilmu umum selama tidak merubah institusinya menjadi Universitas. Begitu juga Sekolah Tinggi Agama Islam (STAI), tidak akan dapat mengembangkan paradigma kajian keilmuannya sebelum merubah diri menjadi sebuah Institut, dan seterusnya. Padahal dalam realitas-praksisnya, paradigma keilmuan yang dibangun dari kedua Perguruan Tinggi Islam tersebut senafas dan sejalan. Demikian persoalan yang seringkali menjadi kendala bagi komunitas Perguruan Tinggi Islam, khususnya bagi para pengelolanya. Hal tersebut biasanya terkait dengan kendalakendala administratif dan birokratif.

Oleh karena itu, ada beberapa istilah yang perlu dijelaskan di sini, yaitu: Institut, Universitas, Sekolah Tinggi, dan bahkan kita juga mencoba untuk menjelaskan Politeknik, dan Akademi sebagai bagian dari lembaga pendidikan tinggi. Menurut Undang-undang Republik Indonesia Nomor 20 Tahun 2003 tentang Sistem Pendidikan Nasional, dinyatakan ${ }^{5}$ bahwa Institut adalah sebuah lembaga pendidikan tinggi yang menyelenggarakan pendidikan

${ }^{5}$ Direktorat Jenderal Pendidikan Islam Depag. RI. 2006. Undang-undang dan Peraturan Pemerintah RI. Tentang Pendidikan. Jakarta: Direkt. Jend. Pend. Islam Depag. RI, h. 57. akademik dan/atau pendidikan vokasi ${ }^{6}$ dalam sekelompok disiplin ilmu pengetahuan, teknologi, dan/atau seni, dan jika memenuhi syarat dapat menyelenggarakan pendidikan profesi, sedangkan Universitas adalah lembaga pendidikan tinggi yang menyelenggarakan pendidikan akademik dan/atau pendidikan vokasi dalam sejumlah ilmu pengetahuan, teknologi, dan/atau seni, dan jika memenuhi syarat dapat menyelenggarakan pendidikan profesi. Sekolah Tinggi adalah pendidikan tinggi yang menyelenggarakan pendidikan akademik dan/atau pendidikan vokasi dalam lingkup satu disiplin ilmu tertentu, dan jika memenuhi syarat dapat menyelenggarakan pendidikan profesi. Adapun Politeknik adalah menyelenggarakan pendidikan vokasi dalam sejumlah bidang pengetahuan khusus. Adapun Akademi adalah menyelenggarakan pendidikan vokasi dalam satu cabang atau sebagian cabang ilmu pengetahuan, teknologi, dan/atau seni tertentu.

Bertolak dari pengertian di atas, istilahistilah tersebut memang secara definitif memunculkan perbedaan makna. Aksentuasi yang terlihat pada institut adalah terletak pada "sekelompok disiplin ilmu pengetahuan, teknologi, dan/atau seni tertentu". Penekanan universitas terletak pada "sejumlah ilmu pengetahuan, teknologi, dan/ atau seni", sedangkan sekolah tinggi menekankan pada "satu disiplin ilmu tertentu". Adapun politeknik aksentuasinya pada "sejumlah bidang pengetahuan khusus". Kemudian pada akademi ditekankan dalam "pendidikan vokasi dalam satu cabang atau sebagian cabang ilmu pengetahuan, teknologi, dan/atau seni tertentu".

Dalam praksisnya yang terjadi di lapangan ternyata tidak semua penentu kebijakan pendidikan di Negeri ini yang taat sepenuhnya terhadap amanat Undang-

${ }^{6}$ Pendidikan vokasi merupakan pendidikan tinggi yang mempersiapkan peserta didik untuk memiliki pekerjaan dengan keahlian terapan tertentu maksimal setara dengan program sarjana. Ibid., h. 55 . 
undang tersebut. Buktinya masih dijumpai dan tidak sedikit institusi pendidikan tinggi yang tidak konsisten untuk melaksanakan aturan tersebut. Misalnya saja, di lingkungan perguruan tinggi Islam, seperti IAI/STAI/PTAI lainnya, mereka tidak hanya membuka fakultas/jurusan/prodi dari sekelompok dan/atau satu disiplin ilmu pengetahuan ke-Islaman semata, namun juga didapati berbagai kelompok dan rumpun ilmu pengetahuan selain ilmu-ilmu ke-Islaman (ilmu umum). Begitu juga yang terdapat pada perguruan tinggi umum semisal politeknik dan akademi. Di sana didapati pula tidak hanya terdiri dari sejumlah bidang pengetahuan khusus, tapi juga merambah kepada bidang kajian keilmuan yang mestinya menjadi wilayah kajian pada perguruan tinggi di tingkat institut dan juga sekolah tinggi. Kondisi seperti ini yang dalam perkembangan selanjutnya membawa konsekuensi pada problem paradigmatik kajian-kajian keilmuan selanjutnya. Termasuk yang terjadi di lembaga pendidikan perguruan tinggi Islam (PTAI).

Dengan demikian, berbicara tentang alih status/transformasi/konversi dari Institut ke-Univeritas, Sekolah Tinggi keInstitut sekiranya bukanlah hal signifikan, jika yang ingin dilakukan perubahan-perubahan adalah menyangkut substansinya. Dengan kata lain, jika ingin merubah PTAI sebagai lembaga par-excelence yang dapat memenuhi segala tuntutan zaman, tidaklah harus melakukan transformasi/konversi kelembagaan. Transformasi dirasa relevan manakala menyangkut perbaikan/ perubahan substansi: visi-misi, bangunan epistemologis, kurikulum, pengembangan SDM, sistem rekruetmen, bangunan kerjasama dengan pihak lain (stakeholders), dan lain-lain. Tentunya harus senantiasa dikorelasikan dengan tuntutan dan kebutuhan, baik pada skala lokal, nasional maupun global.

Meretas Sejarah Kajian ke-Islaman pada

\section{PTAI di Indonesia}

Rencana besar transformasi IAIN menjadi UIN dan/atau STAIN akan di-IAINkan kembali (yang awalnya sebagai IAIN cabang yang berada di daerah-daerah) hingga kini masih debatable dan mengandung berbagai kontroversi. Kontroversi itu muncul sebagai akibat dari perspektif epistemologis yang mempertanyakan, apakah benar selama ini Islam mengikuti dualisme kajian ke-Islaman sebagaimana yang banyak diperdebatkan. Hal ini kemudian menjadi masalah tersendiri. Yang demikian juga tidak dapat dilepaskan dari akibat rendahnya standar mutu manajemen (quality management system), sehingga masalahmasalah tersebut juga sangat berpengaruh terhadap out put yang dianggap tidak atau kurang mampu bersaing di era persaingan global. Oleh karena itu Kementerian Agama mengelindingkan wacana pengembangan IAIN menjadi UIN dan STAIN menjadi IAIN. Dalam perkembangannya wacana tersebut terus menggelinding dan menjamur bagai jamur di musim hujan. Walaupun tidak semua IAIN dan STAIN mengikuti wacana tersebut. Akan tetapi wacana tersebut hampir tidak terdengar lagi gaungnya seiring dengan diterbitkannya Surat Edaran Dirjend Depag RI. No. DJ.II/PP.03.2/698/2006, tgl 2 Agustus 2006 perihal tidak disetujuinya proses usulan baru tentang perubahan status kelembagaan PTAI, kecuali PTAIS yang sudah diproses lebih dulu. Akan tetapi dalam prakteknya, surat edaran Dirjend ini seakan terabaikan seiring dengan munculnya usulan baru alih status dari beberapa perguruan tinggi Islam, dan dalam kenyataannya juga dapat diproses.

Jika dirunut ke belakang, dalam sejarahnya yang panjang, kajian Islam (Islamic studies) di Indonesia sebenarnya bukanlah tumbuh dan berkembang dari realitas historis yang kosong, ia hadir secara kronologis dalam konteks ruang dan waktu yang jelas, sebagai respon sejarah atas sejumlah perso- 
alan keagamaan yang dialami umat Islam di negeri ini. Secara substantif, kajian Islam sebenarnya sudah dimulai semenjak agama ini datang ke Indonesia pada abad ke 13 dan mencapai momentum spiritualnya pada abad ke 17. Kajian ke-Islaman di masa-masa ini diwarnai oleh proses transformasi nilai keagamaan secara besar-besaran yang dilakukan oleh para pemimpin sufi dan ulama, terutama di lembaga-lembaga pendidikan tradisional seperti pesantren. ${ }^{7}$ Proses transformasi ke-Islaman ini berlangsung hingga Indonesia memproklamasikan hari kemerdekaannya pada tanggal 17 Agustus 1945, saat itu bangsa Indonesia dituntut untuk mulai memikirkan dan membenahi proses pelembagaan di segala sektor kehidupan bangsa, tidak terkecuali sektor kehidupan keagamaan sebagai elemen penting, karena bangsa Indonesia adalah bangsa yang sangat religius.

Proses transformasi ke-Islaman pada masa-masa ini tidak bisa dilepaskan dari peran para ulama dan tokoh-tokoh pemimpin gerakan sufi karena diakui terdapat keterkaitan historis yang sangat ekstensif antara umat Islam di Indonesia dengan para ulama di Jazirah Arab seperti Mekah dan Madinah, belakangan Kairo. ${ }^{8}$

Hubungan keagamaan yang sudah sedemikian established di antara kedua komunitas Muslim ini pada gilirannya menciptakan sebuah iklim intellectual exchanges yang relatif dinamis dan dialektis antar mereka. Daratan Jazirah Arab selanjutnya dikenal sebagai oase subur yang memproduksi karya-karya intelektual ke- Islaman yang dikonsumsi oleh masyarakat Muslim di Indonesia. Proses transmisi epistemologis ini berlangsung melalui beragam cara, baik langsung maupun tidak langsung,

${ }^{7}$ M. Atho Mudzhar, "In the Making of Islamic Studies in Indonesia (In Search for a Qiblah)," makalah disampaikan dalam seminar internasional Islam in Indonesia: Intellectualization and Social Transformation, di Jakarta 23-24 November 2000, h. 1.

${ }^{8}$ Azyumardi Azra. 1994. Jaringan Intelektual Ulama Nusantara. Bandung: Mizan, h. 8 mulai dari diseminasi hasil karya-karya intelektual ulama Timur Tengah di banyak lembaga pesantren maupun pengiriman generasi muda Islam yang ingin memperdalam ilmu agamanya ke negara-negara di wilayah ini. ${ }^{9}$

Sekalipun Indonesia memiliki kedekatan hubungan intelektual dengan tradisi keagamaan di Arab, terutama Mekah dan Madinah, itu tidak berarti bahwa Islam Indonesia bisa dikatakan sebagai sekadar replica Islam Arab. Proses transmisi keIslaman dari tradisi intelektual Arab ke tradisi intelektual Indonesia berlangsung dalam pola yang sangat dinamis, unik, dan kompleks, disesuaikan dengan kosmologi keagamaan domestik, sehingga wajah Islam yang berkembang di Indonesia dalam banyak hal bisa berbeda dari wajah Islam "asli" Timur Tengah. Sekalipun demikian, Islam Indonesia tidak serta merta dianggap sebagai Islam pinggiran (peripheral Islam) seperti yang diklaim oleh Geertz. ${ }^{10}$ Pencitraan terhadap Islam Indonesia yang reduktif dan distortif ini bahkan telah dimentahkan oleh Woodward, ${ }^{11}$ Ricklefs, ${ }^{12}$ dan Hefner ${ }^{13}$ yang tetap memandang Islam di negeri ini sebagai varian keagamaan yang tidak tercerabut dari akar-akar meminjam istilah Fazlur Rahman, "Islam normatif". ${ }^{14}$ Persoalan wajah Islam Indonesia yang berbeda dari wajah Islam Timur Tengah dikatakan mereka hanya pada dataran kultural historis semata akibat proses adaptasi, asimilasi

${ }^{9}$ Mona Abaza. 1994. Indonesian Students in Cairo. Paris: EHESS, h. 18

${ }^{10}$ Clifford Geertz. 1960. The Religion of Java. London: The Free Press of Glencoe, h. 18

${ }^{11}$ Mark R. Woodward. 1989. Islam in Java, Normative Piety and Mysticism in the Sultanate of Yogyakarta. Tucson: The University of Arizona Press

${ }^{12}$ Merle C. Riclefs. 1979. Six Centuries of Islamization in Java, dalam Nehemia Levtzion (ed.), Conversion to Islam. New York: Holmes and Meir, h. 100128

${ }^{13}$ Robert W. Hefner. 1987. Islamizing Java? Religion and Politics in Rural East Java. The Journal of Asian Studies 46: 3 (August 1987), h. 533-54

${ }^{14}$ Fazlur Rahman. 1980. Islam. Chicago: The University of Chicago Press, h. 45 
dan akulturasi dalam jangka waktu yang relatif panjang, bukan pada dataran substantif doktrinalnya.

Sebagai bukti bahwa proses transmisi ke-Islaman di Indonesia berlangsung secara unik dan kompleks bisa dijustifikasi melalui proses belajar mengajar yang berlangsung di lembaga pesantren yang mengambil bentuk dan modus operandi cukup unik. ${ }^{15}$ Di daratan Arab sendiri tidak ditemui padanan istilah pesantren yang secara terminologis berarti tempat berlangsungnya proses belajar mengajar antara kyai dan santri di sebuah asrama bersama antara mereka. Istilah santri sendiri bukan berasal dari bahasa Arab, melainkan berasal dari bahasa Jawa kuno (Pallawa), cantrik, yang berarti murid atau siswa yang sedang menuntut ilmu-ilmu kerohanian. Pengadopsian khasanah budaya domestik ini menjadi legitimasi betapa Islam Indonesia sarat dengan muatan-muatan material non-Islam yang tidak bisa dijumpai di negara asalnya, yaitu Arab. Keunikan di tingkat budaya ini menjadi penguat proses pelembagaan kajian ke-Islaman di wilayah non-Arab seperti Indonesia.

Keunikan lain yang bisa dijumpai dari fenomena pesantren adalah digunakannya bahasa "Arab pegon" (Arab Jawi), yakni gabungan antara bahasa Jawa yang ditulis dengan karakter huruf Arab sebagai sarana memahami sejumlah teks-teks kitab kuning yang berbahasa Arab. Bahkan bahasa Arab pegon ini tidak saja digunakan di lembaga-lembaga pesantren di Indonesia, tetapi juga digunakan di dunia Melayu (kini Malaysia, Pattani, dan Brunei Darussalam). ${ }^{16}$ Tidak seperti di belahan dunia Islam lainnya, terutama di Timur Tengah yang tetap menggunakan bahasa Arab sebagai sarana pengkajian ke-Islaman, tradisi intelektual

${ }^{15}$ Zamakhsyari Dhofier. 1989. Tradisi Pesantren, (Jakarta: LP3ES, h. 5

${ }^{16}$ Anthony Reid, "Introduction," dalam Anthony Reid (ed.), 1993. The Making of an Islamic Political Discourse in Southeast Asia. Centre of Southeast Asian Studies: Monash University, h. 1-4. di Jawa berkembang dalam bahasanya sendiri, sementara tidak meninggalkan nuansa bahasa Arab sebagai bahasa penting bagi kajian ke-Islaman secara umum.

Proses pelembagaan kajian Islam dalam pesantren terus berlangsung seiring dengan terjadinya proses transformasi dan modernisasi lembaga tradisional ini. ${ }^{17}$ Proses transformasi dan modernisasi ini terjadi ketika kolonial Belanda memperkenalkan sistem pendidikan sekolah kepada masyarakat pribumi yang dampaknya dirasakan oleh pesantren melalui penyelenggaraan sistem pembelajaran kelas (classical). Sebagai akibat dari penyelenggaraan pembelajaran model ini, maka berdirilah sekolah-sekolah (madrasah) di lingkungan pesantren yang hanya mengajarkan materi pendidikan agama klasik yang meliputi fiqh, tasawuf, etika Islam, dan lain sebagainya. Bahkan jauh setelah masa kemerdekaan, banyak pesantren yang juga memberikan pengajaran materi sekuler seperti ilmu ilmu bumi (geografi), ilmu hitung (matematika), dan ilmu alam (fisika dan biologi), serta ilmu bahasa (Inggris). Pola pengajaran yang sekuler ini biasanya berlangsung di sejumlah pesantren yang mengadopsi metode pengajaran modern seperti Gontor dan Assalam di Solo, yang kemudian diikuti oleh pesantren-pesantren lainnya dengan pola dan sistem pengajaran yang sama. Proses transformasi dan modernisasi pesantren terutama sepanjang dua dekade terakhir ini mengindikasikan adanya sensibilitas lembaga ini terhadap perubahan zaman yang pada gilirannya turut membentuk tradisi kajian Islam di Indonesia secara keseluruhan. ${ }^{18}$

Salah satu implikasi mendasar adanya proses transformasi lembaga pendidikan ini menyebabkan sebagian elemen masyarakat

${ }^{17}$ Abdurrahman Wahid. 2001. Menggerakkan Tradisi. Yogyakarta: LkiS, h. 37-48

${ }^{18}$ Azyumardi Azra, "The Making of Islamic Studies in Indonesia," makalah disampaikan dalam seminar internasional Islam in Indonesia: Intellectualization and Social Transformation, di Jakarta 23-24 November 2000, h. 4 
muslim menginginkan kehadiran lembaga tinggi bagi pengkajian dan pengajaran Islam (Islamic higher learning institution). Salah satu respon terhadap keinginan semacam ini disuarakan oleh Satiman Wiryosandjojo --seorang pemimpin Masyumi dan belakangan menjadi perdana menteri-- akan pentingnya mendirikan lembaga pengkajian Islam dimaksud melalui harian Pedoman Masyarakat pada tahun $1938 .{ }^{19} \mathrm{Hal}$ ini ditujukan agar status muslim meningkat di hadapan koloni Belanda. Menyambut gagasan tersebut, pada bulan April 1945, empat bulan sebelum proklamasi kemerdekaan Indonesia, sekelompok pemimpin muslim berkumpul di Jakarta guna membentuk sebuah komisi persiapan yang dipimpin oleh Moh. Hatta yang selanjutnya menjadi wakil presiden RI pertama. Tugas komisi ini adalah mempersiapkan pembentukan lembaga tinggi Islam yang diwujudkan pada tanggal 8 Juli 1945 dengan berdirinya Sekolah Tinggi Islam (STI). ${ }^{20}$

Setelah kemerdekaan RI, seiring dengan berpindahnya ibukota akibat revolusi dari Jakarta ke Yogyakarta, maka keberadaan Sekolah Tinggi Islam tersebut mengikuti gerak para aktivis Republik. Pada tanggal 10 April 1946, sebuah perguruan Islam berdiri di Yogyakarta dan kemudian beralih status menjadi Universitas Islam Indonesia (UII) pada tanggal 10 Maret 1948 dengan empat fakultas: Kajian Islam, Hukum, Ekonomi, dan Pendidikan. Sebagai penghargaan pemerintah atas perjuangan umat Islam dalam memperoleh kemerdekaan RI, maka pada tahun 1951 pemerintah meresmikan Perguruan Tinggi Agama Islam Negeri (PTAIN) yang diambilkan dari fakultas Kajian Islam UII yang memiliki empat fakultas: Fakultas Dakwah (belakangan menjadi Fakultas Dakwah dan Ushuluddin), Fakultas Qada' (belakangan menjadi Fakultas Syari'ah), dan Fakultas Tarbiyah. Kurang lebih delapan tahun kemudian Fakultas Adab ditambahkan melengkapi keempat

\footnotetext{
${ }^{19}$ Mudzhar, "In the Making", h. 2

${ }^{20}$ Mudzhar, "In the Making", h. 2
}

fakultas yang ada setelah ia diintegrasikan dengan ADIA (Akademi Dinas Ilmu Agama) di Jakarta, sebuah akademi yang didesain untuk mempersiapkan calon-calon tenaga kepegawaian di Departemen Agama RI. ${ }^{21}$

Integrasi kedua lembaga pendidikan tinggi Islam di atas melahirkan sebuah lembaga pengkajian Islam yang kemudian disebut sebagai Institut Agama Islam Negeri (IAIN) dengan lima fakultas: Dakwah, Ushuluddin, Shari'ah, Tarbiyah, dan Adab. Sementara IAIN Yogyakarta tetap berdiri secara independen, lembaga serupa di Jakarta juga berdiri sebagai lembaga independen. Keduanya merupakan lembaga pendidikan tinggi Islam tertua di Indonesia. ${ }^{22}$ Belakangan ini, muncul ide di kalangan pembuat kebijakan pendidikan tinggi Islam untuk mengembalikan semangat kajian Islam yang lebih komprehensif lagi; disiplin keilmuan yang dicakup IAIN

${ }^{21}$ Mudzhar, "In the Making", hal. 2, Cf. Azra, "The Making", h. 4

${ }^{22}$ Belakangan jumlah lembaga yang sama di seluruh Indonesia menjadi 14 IAIN; 7 buah di Sumatera, 5 di Jawa, 1 di Kalimantan, dan selebihnya di Sulawesi, beserta semua cabang masing-masing. Pada tahun 1997, cabang-cabang masingmasing ke 14 IAIN tersebut ditransformasikan ke dalam lembaga pendidikan tinggi Islam yang lebih kecil lagi tapi independen yang disebut sebagai Sekolah Tinggi Agama Islam Negeri (STAIN) yang keseluruhannya berjumlah 33 buah dan tersebar diseluruh pelosok tanah air. Di samping lembaga-lembaga tinggi Islam Negeri ini, sejumlah perguruan tinggi dan universitas swasta juga berdiri di mana fakultas kajian Islam mengambil tempat di dalamnya. Jumlah mahasiswa di seluruh IAIN dan STAIN seluruh Indonesia, menurut data yang dihimpun oleh DEPAG adalah 90.000 orang. Jumlah ini dambil dari buklet Direktorat Pembinaan Perguruan Tinggi Agama (Jakarta: Departemen Agama RI, 2000). Data tersebut sudah berubah, di mana 6 dari 14 IAIN tersebut berubah menjadi UIN (UIN Syarif Hidayatullah Jakarta, UIN Sunan Kalijaga Yogyakarta, UIN Sunan Gunung Jati Bandung, UIN Sultan Syarif Qasim Pekanbaru, UIN Maulana Malik Ibrahim Malang, dan UIN Alauddin Makasar). Begitu juga STAIN yang berjumlah 33, kemudian ada 3 STAIN yang mentransformasikan diri menjadi IAIN, yaitu: IAIN Mataram, IAIN Serang, dan IAIN Slt. Amal Gorontalo. Dengan demikian jumlah IAIN ada 12, UIN ada 6, STAIN menjadi 30, dan jumlah PTAIS ada 272. Lihat: www.ditpertais.net. 
tidak melulu meliputi disiplin ilmu agama semata, namun juga ilmu-ilmu umum yang bernuansa ke-Islaman, seperti psikologi, komunikasi, sosiologi, antropologi, dan lain sebagainya. Ke depan, IAIN akan dikembangkan dalam bentuk Universitas Islam Negeri (UIN) yang membawahi bidang kajian ke-Islaman dan ilmu-ilmu sekuler.

\section{Problem Paradigmatik Kajian ke-Islaman di PTAI}

Rencana besar transformasi IAIN menjadi UIN sebagaimana dijelaskan di atas didasari oleh kesadaran futuristik umat Islam terhadap urgensi penguasaan ilmu pengetahuan dan teknologi dalam menyesuaikan diri dengan akselerasi perubahan zaman yang begitu cepat. Selain itu, transformasi itu muncul sebagai wujud kesadaran umat Islam yang tidak mau mengikuti pola dualisme keilmuan, antara ilmu-ilmu ke-Islaman dan ilmu-ilmu sekuler, sebagai dampak historis kebijakan kolonialisme Belanda. Namun terlepas dari nilai tambah proses transformasi semacam ini, terdapat problem paradigmatik kajian ke-Islaman di PTAI. Hal ini yang di kemudian fenomena pengembangan IAIN menjadi UIN masih debatable dan menyimpan banyak kontroversi. Kontroversi itu antara lain muncul dari perspektif epistemologis yang mempertanyakan apakah benar selama ini Islam mengikuti dualisme kajian ke-Islaman sebagaimana yang banyak diperdebatkan. Sebenarnya langkah rekonsiliasi epistemologis tersebut tidak harus dilakukan dengan cara mengembangkan IAIN menjadi UIN yang membawahi disiplin ilmu agama maupun sekuler. Sebab universitas-universitas negeri yang selama ini dianggap sekuler pun pada hakikatnya merupakan bagian dari umat Islam. Bukankah dengan dibukanya jurusan-jurusan umum di IAIN justru akan semakin merunyamkan sistem penyelenggaraan pendidikan tinggi di Indonesia? Bukankah kehadiran keduanya menjadi saling overlapping antara yang satu dengan lainnya?
Terlepas dari persoalan kontroversi transformasi IAIN menjadi UIN, hal menarik yang perlu digarisbawahi di kalangan IAIN/PTAI adalah kecenderungan kajian Islam yang berlangsung di dalamnya. Sejak berdirinya, lembaga pendidikan tinggi Islam ini membawa dua tugas utama: sebagai lembaga keagamaan dan sebagai lembaga keilmuan. Sebagai sentral pengkajian keagamaan, IAIN/PTAI membawa misi religius untuk memberikan pencerahan masyarakat muslim dalam memahami ajaran Islam (lembaga dakwah). Sedangkan sebagai lembaga keilmuan, IAIN/PTAI diharapkan menjadi avant garde dalam mengkaji Islam sebagai sebuah disiplin akademis, bukan sebagai doktrin agama. ${ }^{23}$ Kedua fungsi ini tidak selamanya berjalan secara harmonis dan berseiringan, bahkan tidak jarang ditemukan konflik di antara keduanya. Di satu sisi, sebagai sebuah lembaga akademis, IAIN/PTAI harus mengikuti rules of the game kehidupan akademis yang memperlakukan kajian terhadap agama dengan mengunakan pendekatan-pendekatan ilmiah dan akademis yang hasilnya tidak jarang bertentangan dengan aspek normatif Islam. Di sisi lain, IAIN/PTAI diharapkan berfungsi sebagai lembaga keagamaan yang cenderung menafikan prinsip-prinsip akademis murni.

Dalam sejarah perkembangannya, IAIN/PTAIdi Indonesia pernah didominasi oleh pendekatan kajian normatif doktrinal yang lebih mengedepankan dimensi legal formal Islam (shari'ah) dan teologi (ushul ad-din). Hal yang demikian terjadi sebagai implikasi logis dari terlalu mengedepannya karakteristik IAIN/PTAI sebagai lembaga keagamaan. Hasil dari pendekatan ini adalah munculnya kecenderungan kajian Islam yang sangat skriptural, mengacu kepada praktik-praktik ibadah dan akidah dalam Islam. Hal ini, menurut Azra, disebabkan oleh dominasi pendekatan normatif-idealis-

${ }^{23}$ Azyumardi Azra, "Studi-studi Agama di Perguruan Tinggi Agama Islam Negeri," dalam Pendidikan Islam, (Jakarta: Logos, 1999), h. 169-70 
tik yang dikembangkan di sejumlah perguruan tinggi Islam Timur Tengah, utamanya al-Azhar Kairo. ${ }^{24}$ Bahkan yang lebih parah lagi, IAIN/PTAI cenderung memfokuskan diri pada satu aliran pemikiran (school of thought) atau madzhab dalam Islam. Sementara madzhab pemikiran Islam yang lain tidak dipelajari karena dianggap akan menyesatkan bangunan keimanan mereka.

Berkenaan dengan pelembagaan tradisi kajian Islam di IAIN/PTAI yang cenderung normatif teologis itu, sejumlah kritik menarik telah dilontarkan oleh Sudirman Tebba. Menurutnya, IAIN/PTAI telah gagal mengembangkan tradisi keilmuan klasik yang fondasinya telah diletakkan oleh para 'ulama. Kegagalan tersebut tidak hanya pada pengembangan metode kajian Islam di bidang hukum Islam saja, tetapi juga di bidang teologi. Misalnya di bidang fiqh, landasan berpikir yang telah diletakkan oleh para ulama tersebut tidak dimanfaatkan dengan baik oleh masyarakat IAIN/PTAI lainnya, akan tetapi yang dipelajari oleh mereka justru produk hukumnya, bukan metode ijtihadnya. Akibatnya, IAIN/PTAI tidak mampu menghadirkan citra Islam yang dinamis, melainkan citra stagnan. Sementara itu di bidang teologi, IAIN/PTAI juga hanya berkutat pada kajian historis pemikiran para ulama klasik seperti pemikiran Mu'tazilah, Ash'ariyah dan Maturidiyah yang terlepas sama sekali dari analisis konteks realita sosial yang mengitarinya. ${ }^{25}$ Sebagai akibatnya, kajian tersebut lebih merupakan refleksi romantisisme masyarakat IAIN/PTAI yang mendambakan masa kejayaan umat Islam seperti terjadi pada abad pertengahan.

Namun demikian, kecenderungan kajian Islam yang demikian normatif teologis tersebut tidak berlangsung selamanya, sebab kecenderungan baru muncul sebagai respons IAIN/PTAI terhadap fenomena

${ }^{24}$ Azra, "The Making", hal. 6

${ }^{25}$ Sudirman Tebba. 1993. "Orientasi Mahasiswa dan Kajian Islam IAIN," dalam Islam Orde Baru. Yogyakarta: Tiara Wacana, h. 83-92 pembangunan dan perubahan zaman. Kecenderungan kajian Islam yang terjadi di awal dekade 1970-an ini lebih mengarah pada kajian Islam yang terkait dengan konteksnya, bersifat sosio-kultural yang menyejarah. Program pembangunan nasional yang mengambil modernisasi sebagai tujuannya cenderung menggiring kaum intelektual muslim seperti Nurcholish Madjid, Harun Nasution ${ }^{26}$ dan Mukti Ali untuk mereorientasi arah kajian Islam yang berlangsung di IAIN (Sekadar untuk diketahui, ketiga orang tersebut juga produk dari pendidikan Barat). Kecenderungan perubahan pendekatan ini bahkan semakin diperlancar dengan dikirimkannya para intelektual muda muslim ke barat untuk meneruskan jenjang studinya.

Hasil paling mendasar dari upaya reorientasi visi kajian Islam di lembaga tinggi Islam ini adalah heterogenitas pendekatan terhadap Islam; Islam tidak hanya dilihat dari satu pendekatan atau madzhab pemikiran saja, melainkan juga berbagai madzhab pemikiran lain yang belum pernah diajarkan di IAIN/PTAI lain. Pendekatan kajian Islam semacam ini turut memberikan kontribusi terhadap diterapkannya metode pengkajian Islam yang lebih empiris dan akademis, tanpa menegasikan kenyataan Islam sebagai sistem keyakinan dan agama. Sebagai akibatnya, mahasiswa cenderung lebih terbuka dan toleran terhadap upaya

${ }^{26}$ Betapa pemikiran pembaruan Islam memiliki dampak yang begitu ekstensif di IAIN bisa dilihat dari digunakannya karya-karya teks Harun Nasution sebagai literatur wajib bagi mahasiswa IAIN. Terlebih ketika dia memimpin IAIN Syarif Hidayatullah Jakarta dan belakangan direktur program pasca sarjana di lembaga yang sama. Dalam diskursus kajian teologi ke-Islaman, barangkali dialah yang pertama kali meletakkan landasan berteologi secara kritis-rasional terhadap doktrindoktrin akidah Islam. Ia pula yang secara terang-terangan memproklamirkan diri sebagai pendukung utama aliran Mu'tazilah dalam berteologi yang senantiasa mengedepankan proses berpikir rasional. Lihat Richard Martin et. al., "Harun Nasution and Modern Mu'tazilism," dalam Richard Martin (ed.). 1997. Defenders of Reason in Islam.Oxford: Oneworld, h. 119-179 
pemahaman agama yang berbeda. ${ }^{27}$ Kondisi ini pada gilirannya mendorong lahirnya pendekatan non-madzhabi dalam kajian Islam di Indonesia, seiring dengan semakin memudarnya loyalitas dan fanatisme buta umat Islam terhadap madzhab tertentu. ${ }^{28}$

Dimensi lain dari fenomena perubahan pendekatan dalam kajian Islam di IAIN dan PTAI pada umumnya adalah semakin sadarnya umat Islam terhadap realitas sosio-kultural mereka. Kesadaran semacam ini bahkan membawa pada implikasi radikal terhadap redefinisi relasi agamamanusia; apakah manusia didedikasikan untuk agama ataukah sebaliknya, agama untuk manusia. Pendekatan normatif jelas mengandaikan relasi yang menempatkan agama sebagai target pengabdian manusia. Sementara itu, pendekatan kontekstual empiris mengandaikan relasi yang menempatkan agama sebagai sarana untuk mengatur kehidupan manusia di dunia, bukan untuk kepentingan-kepentingan ukhrawi manusia semata. Jadi, agama sebagai way of life, mediasi yang mengantarkan manusia untuk mendapatkan ridla Allah. Bukan agama sebagai tujuan akhir seperti yang diasumsikan dalam pendekatan normatif teologis.

Perubahan pendekatan kajian Islam di IAIN/PTAI juga membawa konsekuensi perubahan pendekatan dalam memandang realitas agama lain selain Islam. Se-

${ }^{27}$ Kekhawatiran terjadinya degradasi kualitas keimanan seseorang ketika menerapkan metode ilmiah dalam kajian agama sebenarnya sudah pernah dijawab oleh Max Müller dalam karyanya Introduction to the Science of Religion (1873). Dia mengatakan bahwa pendekatan scientific dalam kajian agama tidak seharusnya menambah keraguan terhadap keyakinan agama si peneliti, melainkan justru bisa semakin memperkokoh bangunan keimanannya. Hal yang demikian ini bisa terjadi ketika si peneliti mampu melakukan pemaknaan-pemaknaan yang cukup berarti terhadap hasil-hasil temuannya untuk kemudian diinternalisasikan dalam sistem keimanannya sendiri. Periksa, Peter Connolly, "Psychological Approaches," dalam Peter Connolly. 1999. Approaches to the Study of Religion. London \& New York: Casell, h. 139

$$
{ }^{28} \text { Azra, "The Making," h. } 7
$$

belumnya, pendekatan dalam mengkaji agama-agama lain cenderung menerapkan pendekatan apologetik untuk menjustifikasi kebenaran Islam atas agama-agama lain. Sementara itu, komunitas non-Islam dianggap sebagai orang kafir yang halal darahnya untuk dibunuh. Terutama sejak Mukti Ali kembali dari Canada setelah menyelesaikan program MA-nya, pendekatan dalam kajian perbandingan agama berubah secara radikal. Paradigma truth claim yang dianut sejak lama oleh IAIN/PTAI secara bertahap mengalami pergeseran dan digantikan oleh paradigma berpikir yang lebih toleran, inklusif, dan pluralistik di mana kehadiran agama-agama yang berbeda di muka bumi ini dianggap sebagai hukum alam (sunnatullah) yang tidak bisa dinafikan begitu saja. Kehadiran mereka tidak boleh diperangi sepanjang tidak membuka perlawanan dengan umat Islam, dan di antara mereka terikat hukum mu'amalah yang saling mengikat. Perubahan paradigma ini semakin diperkokoh dalam tatanan khidupan beragama secara nasional ketika Mukti Ali diangkat sebagai Menteri Agama RI. ${ }^{29}$

Sebuah pertanyaan mendasar telah dimunculkan oleh Atho Mudzhar berkenaan dengan kajian Islam di IAIN dan juga pada PTAI umumnya. Pertama, dengan adanya transformasi besar-besaran dalam bidang kajian Islam di lembaga ini, harus dirumuskan secara tegas mana kajian ilmu yang termasuk inti dan mana yang termasuk ilmuilmu bantu? Pertanyaan ini penting untuk dijawab mengingat transformasi kajian Islam di IAIN/PTAI yang semakin diperkaya dengan berbagai pendekatan dan perspektif "sekuler" itu bukan bertujuan untuk mengerdilkan kajian Islam itu sendiri, melainkan agar kajian Islam bisa ditopang oleh bidang kajian yang lebih membumi,

${ }^{29}$ Nico Kaptein, "The Transformation of the Academic Study of Religion: Examples from Netherlands and Indonesia," makalah disampaikan dalam seminar internasional Islam in Indonesia: Intellectualization and Social Transformation, di Jakarta 23-24 November 2000, hal. 11 
menyejarah dan empiris. Dalam perspektif ini, fiqh, misalnya, harus diklasifikasikan sebagai ilmu inti atau ilmu bantu. Demikian pula sosiologi ataupun antropologi, termasuk ilmu inti atau ilmu bantu? Ini semua dalam rangka mendudukkan persoalan secara proporsional, jangan sampai ada gejala overlapping antara satu dan lainnya. ${ }^{30}$ Kedua, Bagaimana cara mendekati Islam normatif yang bersifat dogmatis teologis itu? Sebagai konsekuensi logis dari pertanyaan ini, perlu dimunculkan studi antar dan interdisipliner untuk memahami fenomena Islam ideal ke dalam kerangka historisnya. Ketiga, berpijak pada serangkaian pertanyaan di atas, sudah waktunya bagi IAIN/PTAI lain untuk membuka program studi-program studi (prodi) umum untuk membangun pemahaman Islam yang lebih komprehensif seperti yang telah dilakukan di al-Azhar dan sejumlah universitas lain di dunia Islam, ${ }^{31}$ tidak harus mengubah/ mengganti identitas "Pendidikan Tinggi Islam"-nya dan atau merubah "institusi"nya, misalnya dari Institut menjadi Universitas, Sekolah Tinggi menjadi Institut, dan sebagainya.

Namun demikian, kondisi sosio-kultural bagi kedua lembaga pendidikan tinggi Islam dimaksud nampaknya tidaklah sama. Barangkali setting Mesir agak bersahabat bagi dibukanya full-fledged university seperti al-Azhar, sementara Indonesia agak kompleks. Sekalipun demikian, IAIN/PTAI tetap harus mengevaluasi ulang misi orisinalnya sebagai pijakan disusunnya ilmu inti (core subjects) dan ilmu bantu (auxiliary subjects). Persoalannya, bagaimana melakukan itu semua?

${ }^{30}$ Atho Mudzhar. 1998. Pendekatan Studi Islam dalam Teori dan Praktek. Yogyakarta: Pustaka Pelajar, h. 29 31

${ }^{31}$ Atho Mudzhar, Pendekatan Studi Islam, h. 30-

\section{PENUTUP}

\section{Kesimpulan}

Fenomena tentang alih status/transformasi/konversi dari Institut ke-Univeritas, Sekolah Tinggi ke-Institut sekiranya bukanlah hal signifikan, jika yang ingin dilakukan perubahan-perubahan adalah menyangkut substansinya, artinya, jika ingin merubah PTAI sebagai lembaga par-excelence yang dapat memenuhi segala tuntutan zaman, tidaklah harus melakukan transformasi/ konversi kelembagaan. Transformasi dirasa relevan manakala menyangkut perbaikan/ perubahan substansi: visi-misi, bangunan epistemologis, kurikulum, pengembangan SDM, sistem rekruitmen, bangunan kerjasama dengan pihak lain (stakeholders), dan lain-lain. Tentunya harus senantiasa dikorelasikan dengan tuntutan dan kebutuhan, baik pada skala lokal, nasional maupun global.

Rencana besar transformasi IAIN menjadi UIN dan/atau STAIN akan di-IAINkan kembali hingga kini masih debatable dan mengandung berbagai kontroversi. Kontroversi itu muncul sebagai akibat dari perspektif epistemologis yang mempertanyakan, apakah benar selama ini Islam mengikuti dualisme kajian ke-Islaman sebagaimana yang banyak diperdebatkan. Hal ini kemudian menjadi masalah tersendiri, sehingga masalah-masalah tersebut juga sangat berpengaruh terhadap out put yang dianggap tidak atau kurang mampu bersaing di era persaingan global.

Dari pemetaan problem paradigmatik kajian ke-Islaman pada PTAI sebagaimana diuraikan di atas, nampaknya ada dua upaya besar yang mesti dilakukan PTAI untuk mengejar ketertinggalan-ketertinggalan selama ini, yaitu upaya yang bersifat intern dan ekstern.

1. Bersifat intern, adalah upaya perbaikan paradigma kajian keilmuan (epistemologis)-nya, tidak terjebak pada dikotomisasi ilmu, menentukan pilihan seba- 
gai lembaga dakwah, akademis, dan atau praktis pragmatis, memperkuat SDM, memperbaiki dan menyesuaikan kurikulumnya dengan tuntutan perubahan, penambahan sarana-prasarana, peningkatan anggaran, memperkuat jaringan (stakeholders), pembenahan sistem rekruetmen, dan lain-lain.

2. Bersifat ekstern, adalah dengan cepatnya persaingan global, regional dan lokal seperti sekarang ini, dengan menjamurnya Perguruan Tinggi-Perguruan Tinggi baik Negeri maupun Swasta di lingkungan PTAI, dengan program dan produk yang sama, dan atau lebih menjanjikan; tentu akan membuat persoalan tersendiri bagi PTAI yang dikelola dan dikembangkan, jika tidak memacu diri ikut berkompetisi secara dinamis. Tentunya dengan tawaran produk yang lebih menjanjikan.

3. Barangkali hal yang mesti disiapkan adalah dengan segala upaya bagaimana PTAI bisa tetap survive dan dapat memenuhi tuntutan dan kebutuhan di tengah transformasi sosial yang hebat seperti sekarang ini. Di antaranya adalah dengan membangun dan memperkuat jaringan (stakeholders) dengan berbagai pihak, baik dengan pihak Negeri maupun swasta; baik dalam maupun luar negeri. Sudah saatnya PTAI melakukan upaya-upaya tersebut demi persaingan di tengah kapitalisme global, tanpa harus merubah "status kelembagaan dan atau institusinya".

\section{SUMBER BACAAN}

Abaza, Mona (1994): Indonesian Students in Cairo. Paris, EHESS.

Azra, Azyumardi (1999): "Studi-studi Agama di Perguruan Tinggi Agama Islam Negeri," dalam Pendidikan Islam. Jakarta, Logos.

----------, “The Making of Islamic Studies in Indonesia," makalah disampaikan dalam seminar internasional Islam in Indonesia: Intellectualization and Social Transformation, di Jakarta 23-24 November 2000

--, "Pendidikan Tinggi Islam dan Kemajuan Sains (Sebuah Pengantar)", dalam Charles Michael Stanton (1994): Pendidikan Tinggi dalam Islam, (terj.) H. Afandi dan Hasan Asari. Jakarta, Logos.

(1994): Jaringan Intelektual Ulama Nusantara. Bandung, Mizan.

Boullata, Issa J., Classical Exegesis (Tafsir I), di Institute of Islamic Studies, McGill University, Canada, semester Summer, September-Desember 1997

Connolly, Peter, "Psychological Approaches," dalam Peter Connolly (1999): Approaches to the Study of Religion. London and New York, Casell.

DEPAG RI., (2000): Buklet Direktorat Pembinaan Perguruan Tinggi Agama. Jakarta, Departemen Agama RI.

Dhofier, Zamakhsyari (1985): Tradisi Pesantren. Jakarta, LP3ES.

Direktorat Jenderal Pendidikan Islam Depag. RI (2006): Undang-undang dan Peraturan Pemerintah RI. Tentang Pendidikan. Jakarta, Direkt. Jend. Pend. Islam Depag. RI.

Geertz, Clifford (1960): The Religion of Java. London, The Free Press of Glencoe.

Hefner, Robert W., "Islamizing Java? Religion and Politics in Rural East Java." The Journal of Asian Studies 46: 3 (August 1987)

Hidayat, Komaruddin dan Hendro Prasetiyo (ed.), (2000): "Menilik Dinamika IAIN", dalam Problem dan Prospek IAIN: Antologi Pendidikan Tinggi Islam, Ditpertais Depag. RI.

Jeffery, Arthur (1958): Islam: Muhammad and His Religion. New York, Library of Liberal Arts. 
Kaptein, Nico, "The Transformation of the Academic Study of Religion: Examples from Netherlands and Indonesia," makalah disampaikan dalam seminar internasional Islam in Indonesia: Intellectualization and Social Transformation, di Jakarta 23-24 November 2000

Madjid, Nurcholish (1966): Islam Doktrin dan Peradaban. Jakarta, Paramadina.

Martin, Richard et. al., "Harun Nasution and Modern Mu'tazilism," dalam Richard Martin (ed.) (1997): Defenders of Reason in Islam. Oxford, Oneworld.

Mudzhar, M. Atho (1998): Pendekatan Studi Islam dalam Teori dan Praktek. Yogyakarta, Pustaka Pelajar.

"In the Making of Islamic Studies in Indonesia (In Search for a Qiblah)," makalah disampaikan dalam seminar internasional Islam in Indonesia: Intellectualization and Social Transformation, di Jakarta 23-24 November 2000

Rahman, Fazlur (1980): Islam. Chicago, The University of Chicago Press.
Rais, Amien (1991): Cakrawala Islam. Bandung, Mizan.

Reid, Anthony, "Introduction," dalam Anthony Reid (ed.), (1993): The Making of an Islamic Political Discourse in Southeast Asia. Centre of Southeast Asian Studies, Monash University

Riclefs, Merle C., "Six Centuries of Islamization in Java," dalam Nehemia Levtzion (ed.), (1979): Conversion to Islam. New York, Holmes and Meir

Tebba, Sudirman (1993): “Orientasi Mahasiswa dan Kajian Islam IAIN," dalam Islam Orde Baru. Yogyakarta, Tiara Wacana

Tibi, Bassam, (1991): Islam and the Cultural Accommodation of Social Change. Boulder.

Wahid, Abdurrahman (2001): Menggerakkan Tradisi. Yogyakarta, LKiS.

Woodward, Mark R., (1989): Islam in Java, Normative Piety and Mysticism in the Sultanate of Yogyakarta. Tucson, The University of Arizona Press. 